\title{
POTENTIALITIES OF THE USE OF AGROFORESTRY SYSTEMS IN THE BRAZILIAN SEMI-ARID REGION
}

\author{
João Paulo de Oliveira Santos ${ }^{1}$, Murilo Araújo Xavier ${ }^{2}$, José Adalberto da Silva Filho ${ }^{1}$, Mateus Costa Batista ${ }^{3}$, \\ Fernando Cartaxo Rolim Neto ${ }^{1}$
}

${ }^{1}$ Universidade Federal Rural de Pernambuco - UFRPE, Programa de Pós-Graduação em Engenharia Ambiental. 2Universidade Federal da Paraíba - UFPB, Curso de Agronomia. ${ }^{3}$ Universidade Federal de Campina Grande - UFCG, Programa de Pós-Graduação em Engenharia Agrícola. E-mail: jpos@agro.adm.br

\begin{abstract}
The mode of exploration of the Brazilian semiarid has followed since the colonization of Brazil, a model of exacerbated extraction of the natural resources. This model has led to the severe environmental degradation of this region and mainly of its main biome, the Caatinga. In this context, several farmers have sought new forms of production, with emphasis on Agroforestry Systems (SAFs). This system involves trees, shrubs, agricultural crops and animals in the same area, seeking to maximize socioeconomic, cultural and environmental values, since they have the potential to enhance the production of environmental goods and services. Although this practice to occur for decades by farmers in the country, its study as a science is relatively recent, and its potentiality is still unknown. Several studies demonstrate the application of this technique in the semi-arid region, with results that show improvements in soil quality, nutrient cycling, biological fixation, income generation among small producers, among others. However, there is still a lack of incentive for government agencies to further disseminate this practice among farmers in this region, as well as information on the social, environmental and economic benefits of SAFs.
\end{abstract}

Keywords: caatinga; sustainable development; integration.

\section{POTENCIALIDADES DO USO DE SISTEMAS AGROFLORESTAIS NO SEMIÁRIDO BRASILEIRO}

\section{RESUMO}

O modo de exploração do semiárido brasileiro conduziu-se desde a colonização, na exploração acentuada dos recursos naturais. Esse modelo tem levado a degradação ambiental severa dessa região e principalmente, do seu principal bioma, a Caatinga. Nesse contexto, diversos agricultores têm buscado novas formas de produção, dando destaque aos Sistemas Agroflorestais (SAFs). Esses sistemas consistem na combinação de árvores, arbustos, cultivos agrícolas e animais na mesma área, procurando a maximização dos valores socioeconômicos, culturais e ambientais, uma vez que, apresentam capacidade de potencializar a produção de bens e serviços ambientais. Essa prática já vem sendo utilizada durante décadas, por agricultores espalhados no país. O estudo como ciência é relativamente recente, sendo sua potencialidade ainda desconhecida. Diversos trabalhos demonstram a aplicação dessa técnica no semiárido, com resultados que mostram melhorias na qualidade do solo, na ciclagem de nutrientes, na fixação biológica, na geração de renda, entre outros. No entanto, ainda falta incentivo do poder público para uma maior disseminação nessa prática, entre os agricultores dessa região, sobretudo, a falta de informações sobre os benefícios sociais, ambientais e econômicos oriundos dos SAFs.

Palavras-chave: caatinga; desenvolvimento sustentável; integração.

\section{INTRODUCTION}

Historically, the implantation of agricultural systems in Brazilian territory has been linked to deforestation and the intensified use of natural resources, considered by the settlers and by many producers as inexhaustible
(ENGEL, 2003). Based on this context, in order to reduce the fragility of traditional production systems, as well as the effect of the removal of trees in cultivated areas, many farmers are migrating to other forms of exploitation, 
emphasizing agroforestry systems (MARTINS et al., 2013).

Agroforestry Systems (SAFs) are essentially an integrated combination of trees, shrubs and agricultural crops in the same area in spatial and temporal arrangements (SANTOS, 2000; UMRANI; JAIN, 2010) with or without the presence of animals (PALUDO; COSTABEBER, 2012), seeking to maximize socioeconomic, cultural and environmental values, boosting the production of environmental goods and services (ASSIS JÚNIOR et al., 2003; BATISH et al., 2008).

This production model represents a dynamic and complex system, bringing together and valuing traditional knowledge, combined with the contemporary concepts of systemic management of complex organic farming systems, bringing together several benefits and contributions for the sustainability of production, promoting environmental, economic and social benefits (FERREIRA et al., 2016). Environmental stability, water conservation, product diversity, workforce maximization, shelter for wildlife and nutrient cycling should be highlighted (ARAÚJO, 2004).

When compared to conventional land use systems, SAFs have as main objective to allow greater diversity and sustainability (SANTOS; PAIVA, 2002). Among the models of soil exploration, they are the ones that are most ecologically close to the natural forest, constituting an important alternative for the sustainable use of the humid tropical ecosystem (ALMEIDA et al., 2002).

In these systems, individuals develop according to their own growth characteristics and the conditions offered by the ecosystem, taking into account different times and speeds, forming built-up forest systems (LEÃO et al., 2017). In this situation, forest species, besides providing products useful to the farmer, also play an important role in the maintenance of soil fertility (COSTA et al., 2002), through a more efficient cycling of nutrients and reduction of losses by leaching and erosion (GAMA-RODRIGUES et al., 2008).

The SAFs stand out for their high capacity of biomass production and occupation of different tree strata, generating greater efficiency in the use of sunlight and in the exploitation of higher volume of soil (DUBOIS, 2009). Due to being classified as a low environmental impact activity, this system can be applied in areas of permanent preservation and legal reserve, provided that it is carried out by small farmers, settlers of agrarian reform or traditional communities (BRAZIL, 2012).

In order to obtain success in SAFs, it is necessary to consider the correct choice of the species that will compose it, the arrangement between the plants and especially the choice of the place to be implanted (COUTO et al., 2016). Other basic points should also be specified, such as which one or which products to be produced, the destination of these products and what will be effectively produced in the condition of their installation (REZENDE; OLIVEIRA, 2013).

\section{AGROFORESTRY SYSTEMS (SAFS) IN BRAZIL}

Although it is an ancient modality of land use, the study of SAFs as a science is relatively recent, being its initial studies in the country, dating from the beginning of the decade of the 80 (MONTOYA; MAZUCHOWSKI, 1994). In 2009, during the 15th Conference of the Parties (COP$15)$, and based on the levels of greenhouse gas (GHG) emissions in 2005, Brazil signed an agreement that addresses the reduction by 2020 , with a percentage varying from $36.1 \%$ to $38.9 \%$ (TORRES et al., 2014). Aiming to achieve this goal, the Low Carbon Agriculture $(A B C)$ program was created, whose main objective is to encourage the adoption of sustainable practices that guarantee the reduction of GHG emissions, combined with the increase in income of producers, especially with the expansion of recovery of degraded pastures; crop-livestockforest integration (IPPF) and agroforestry systems (SAFs); no-till system (SPD); biological nitrogen fixation (BNF); and planted forests. The goal established by the plan is the implantation of 4 million hectares with the use of crop-livestockforest integration and agroforestry systems by 2020 (BRAZIL, 2012).

Many Brazilian farmers and technicians have a restricted view of the Legal Reserve and Permanent Preservation Areas (PPAs), considering them essentially preservationist purposes, since they are not seen as areas that can be used in a productive way (MOONEN; BARBIERI, 2008). However, the Brazilian Forest Code makes room for the use of agroforestry systems in PPAs, making these areas suitable for other activities (BRAZIL, 2012). Law 12.651 / 2012 defines that the suppression or intervention of native vegetation in APP may occur if it is of public utility, social interest or low environmental 
impact, and agroforestry is applicable, according to the following wording:

"Sustainable
agroforestry
exploitation practiced
on smallholdings or
rural family holdings or
by traditional peoples
and communities, as
long as it does not de-
characterize existing
vegetation cover and
does not jeopardize the
environmental function
of the area (Art. 3,
subsection IX, b).

The CONAMA Resolution 458/2013, in its turn, presents in Article 2, Section IV, that the definitions of low environmental impact include "agroforestry sustainable, community and family forest management, including the extraction of non-timber forest, provided they do not deplete the native vegetation cover existent and do not affect the environmental function of the area "(BRAZIL, 2013).

In Brazil, traditionally these systems predominate in the Amazon region, where the simultaneous agricultural crops with forest species is one of those responsible for the maintenance of soil fertility (SILVA et al., 2011); in southern Bahia, cocoa production is made in the natural forest (MOÇO et al., 2008); (Araucaria angustifolia) and animal creations in the subforest (BARRETO; SAHR, 2007); and in the Ribeira Valley region of São Paulo, traditional communities open clearings in the forest, followed by the use of fire and the establishment of a diverse community of plants, including annual species (MARTINS, 2005).

SAFs have several classifications, which take into account their spatial structure, time design, relative importance and function of the different components, production objectives and socioeconomic characteristics. However, three classifications are the most common and used: Agrosilviculture (crops and forestry) systems, which aggregate forestry and agricultural crops; Silvipastoril (forestry and pasture) systems that refer to the association of pastures and animals and/or trees; Agrosilvipastoril (crops, forestry and pasture) systems that combine agricultural crops, pastures and/or animals and trees (SOUZA et al., 2007).
Among the modalities presented, the agroforestry system can be considered the most complete, involving besides the agricultural crops, the possibility of using the forest essences, integrating the agricultural, forestry and livestock activities into a single system, leading to profit maximization (SILVA et al., 2014). According to Balbino et al. (2011a) it is estimated that the agroforestry system in Brazil occupies an area of about 1.6 million hectares. There is also the availability of 67.8 million hectares with the capacity to be used under this form of exploration, thus avoiding the opening of new areas with native vegetation.

\section{ADVANTAGES AND DISADVANTAGES OF SAFS}

The Agroforestry Systems present a series of advantages for the producer, among them: application in large, medium and small farms; more efficient control of insects, pests, diseases and weeds; contribution of the tree component by the improvement of microclimatic conditions, reduction of the thermal amplitude, increase of the relative humidity of the air and decrease of the intensity of the winds; increase of animal welfare, due to the greater thermal comfort; possibility of using species and cultivars more appropriate for each region; perspective of reducing pressure for the opening of new areas of natural vegetation; mitigation of carbon sequestration, especially by the forage and forest components; intensification of nutrient cycling (BALBINO et al., 2011b); increasing soil cover by straw from crop residues and pasture, preventing losses due to erosion, and increasing diversity (GALZERANO; MORGADO, 2008; BALBINO et al., 2011b); recovery of leached or drained nutrients to deeper soil layers; increase of organic matter deposition via litter (MENDONÇA et al., 2001; BALBINO et al., 2011b); increase in soil porosity and consequently water infiltration to replant groundwater (BALBINO et al., 2011b); income generation by the diversity of products obtained (ARATO et al., 2003).

Notably, one of the major obstacles to the establishment of SAFs in Brazil is due to: lack of understanding of the system; need for greater financial resources to implement the project; return only in the medium and long term, especially the forestry component; incentives still reduced by public bodies; possible competition for nutrients, water and light; allelopathy and 
difficulty in mechanization (BALBINO et al., 2011b).

\section{SAFs IN THE BRAZILIAN SEMI-ARID REGION}

It happens in the semi-arid region of Brazil (Figure 1) since the colonization period, the process of degradation of its natural resources. This process is caused largely by inadequate physical and biological exploitation practices, especially the exhaustive cropping systems, the over grazing in the Caatinga biome, and predatory exploitation of fauna and flora. Added to this scenario is the degradation of water resources, caused by the destruction of forest cover, as a result of deforestation and forest fires (SILVA; GUIMARÃES FILHO, 2006).

Figure 1. Delimitation of the Brazilian Semi-arid

Source. Instituto Nacional do Semiárido (INSA)

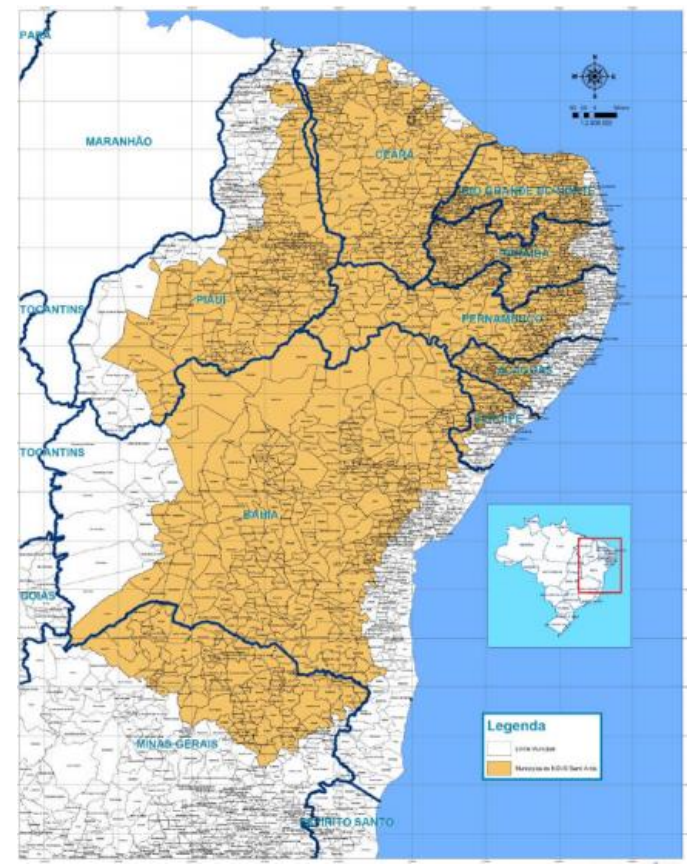

This process of use and occupation of the Brazilian semiarid, in a predatory and unbridled way, has caused great damage to the main biome of the region, the Caatinga. This has led to a gradual reduction of native vegetation (SILVA; ALMEIDA, 2015). According to Riegelhaupt et al. (2010) about $94 \%$ of all the firewood and coal used in the semi-arid region come from the deforestation of the Caatinga. Other human actions such as extensive cattle ranching and farming systems in the most fertile areas also cause deforestation and environmental devastation (SANTANA; SOUTO, 2006).

These anthropogenic pressures make the Caatinga one of the Brazilian ecosystems most threatened by desertification, resulting both from climatic factors as well as from human activities (COSTA et al., 2009). Data from the Monitoring Report on Deforestation in the Caatinga (BRAZIL, 2011), show that $45.4 \%$ of the total area of the biome is altered. Thus, new rational exploration strategies of this region should be employed. Several studies deal with the application of agroforestry systems in the semiarid region. According to Duque (2004) in this region it is necessary to choose xerophytic species for the beginning of the agroforestry succession, thus generating the most favorable environmental ecological conditions, softening the preexisting extreme conditions and opening the possibility of growing more demanding plants.

Studies performed by Aguiar et al. (2014), comparing agroforestry systems, traditional cultivation areas and preserved Caatinga area, showed that the SAFs presented nutrient stocks on average $21 \%$ higher than the traditional area and represent $64 \%$ of the stocks of the conserved Caatinga. The results showed a great potential for nutrient cycling of this system, with annual litter production and nutrient intake higher than that of traditional cultivation and intermediates in relation to that of the conserved vegetation. Maia et al. (2008), also in studies in the semi-arid region of the State of Ceará, have noticed that silvipastoril systems have preserved and, in 
some cases, increased $\mathrm{N}$ levels of soil, constituting, therefore, a system that can be recommended as a sustainable alternative of soil management for this region.

Martins et al. (2013) analyzing agroforestry systems in Taperoá, State of Paraíba, observed that total biomass productivity in agroforestry systems was $260 \%$ higher than in traditional systems. It was verified that the coefficients of variation of annual productivity of biomass were lower in agroforestry systems. In this way, the presence of trees besides increasing the total productivity, also gave greater stability to the systems. The authors later verified that in systems with buffel grass and forage palm, between rows of gliricidia (Gliricidia sepium Jacq.) and maniçoba (Manihot glaziovii Muel Arg), the annual addition of $\mathrm{N}$ by symbiosis with native soil bacteria was $40 \mathrm{~kg}$ per hectare (MARTINS et al., 2015).

Oliveira et al. (2016) working in the semi-arid region of the State of Rio Grande do Norte, with the cultivation of corn between rows of gliricídia (Gliricidia sepium Jacq.) and sabiá (Mimosa caesalpiniaefolia), observed that the number and mass of marketable green corn cobs, with or without straws, were similar to those found in monoculture, besides that this value was obtained with a population of plants smaller than the one practiced in the conventional way. Although the intercropping with the two tree species reduced grain yield, there was no influence on the yield of green corn cobs suitable for trade. There was a reduction of $92 \%$ and $72 \%$ in the costs of implantation of gliricídia (Gliricidia sepium Jacq.) and sabiá (Mimosa caesalpiniaefolia), respectively, if taken as a purpose for the production of grains. The reduction of implementation costs reaches $100 \%$ if the purpose of producing the corn is the commercialization of green corn cobs.

When it comes to soil quality Carvalho et al. (2004) state that under agroforestry, the soil presents lower apparent density, higher porosity, lower resistance to penetration and greater stability of aggregates, when compared to the same soil under conventional planting system. Perez-Marin and Menezes (2008), in a study in the state of Paraíba, concluded that due to the interception of a significant amount of water through the canopy, in SAFs there is less surface runoff and also more water supply to the basement than in traditional agricultural systems. Such mechanisms could lead to lower losses of soil, nutrients and water by erosion, leaching and subsurface flow.

The type of management adopted in agroforestry systems alters the diversity and biomass production of plant communities, especially herbaceous plants. It maintains some arboreal/shrub component diversity parameters similar to native vegetation. On the other hand, considering the agricultural components, the area under agroforestry becomes similar to the preserved Caatinga, in biomass production and plant diversity (AGUIAR et al., 2013).

Some parameters should be observed in SAFs, such as competition among the species. Oliveira et al. (2016) obtained equal diameters of the corn stalk, in single sabiá (Mimosa caesalpiniaefolia) plantation and intercropped with maize. This behavior was different when the maize was intercropped with the gliricídia (Gliricidia sepium Jacq.), resulting in a smaller diameter of the stalk of the corn, in relation to its separate planting. Another important factor is the allelopathic effect among species.These studies are very important in tree plants with the potential to compose agroforestry and silvopastoril systems, thus avoiding future losses (DIÓGENES et al., 2014).

\section{CONCLUSIONS}

Agroforestry Systems constitute sustainable exploration models, presenting great growth potential in the Brazilian Northeast. They add several benefits such as the maintenance of soil quality, diversity of products generated, lower incidence of pests and pathogens, increase of organic matter to the system, among others. In spite of all these benefits, it should be taken into consideration during the implementation of the system for some strategic points such as: which species best suit the region; which consortia are to be used and the allelopathic potential of some of the components of the system.

\section{REFERENCES}

ALMEIDA, C. M. V. C.; MÜLLER, M. W.; SENAGOMES, A. R.; MATOS, P. G. G. Pesquisa em sistemas agroflorestais e agricultura sustentável: manejo do sistema. In: WORKSHOP LATINO-AMERICANO SOBRE 
PESQUISA DE CACAU, Ilhéus, Bahia. Anais... 2002.

AGUIAR, M, I.; FIALHO, J. S.; CAMPANHA, M. M.; OLIVEIRA, T. S. Carbon sequestration and nutrient reserves under different land use systems. Revista Árvore, v.38, n.1, p.81-93, $2014 . \quad$ https://doi.org/10.1590/S0100$\underline{67622014000100008}$

AGUIAR, M.I.; FIALHO, J.S.; ARAÚJO, F.C.S.; CAMPANHA, M. M.; OLIVEIRA, T. S. Does biomass production depend on plant community diversity? Agroforest Syst, v.87, n.3, p. 699-711, 2013. http://dx.doi.org/10.1007/s10457-012-9590-9.

ARATO, H. D.; MARTINS, S. V.; FERRARI, S. H. S. Produção e decomposição de serrapilheira em um sistema agroflorestal implantado para recuperação de área degradada em Viçosa, MG. Revista Árvore, v.27, n.5, p. 715-721, $2003 . \quad$ https://doi.org/10.1590/S0100$\underline{67622003000500014}$

ARAÚJO, P. R. D. Descobrindo agroflorestas nos territórios quilombolas de Oriximiná - PA. São Paulo: Comissão Pró-Índio, 34p. 2004.

ASSIS JÚNIOR S. L.; ZANUNCIO, J. C.; KASUYA, M. C. M.; COUTO, L.; MELIDO, R. C. N. Atividade microbiana do solo em sistemas agroflorestais, monoculturas, mata natural e área desmatada. Revista Árvore, v.27, n.1, p. 35-41, 2003. https://doi.org/10.1590/S0100$\underline{67622003000100005}$

BALBINO, L. C.; BARCELOS, A. O.; STONE, L. F. Marco referencial Integração LavouraPecuária-Floresta. Brasília: Embrapa Cerrados, 130 p., 2011 .

BALBINO L. C., KICHEL A. N.; BUNGENSTAB D. J.; ALMEIDA, R. G. Sistemas de integração: o que são, suas vantagens e limitações. In: BUNGENSTAB D. J (Ed). Sistemas de integração Lavoura-Pecuária-Floresta: a produção sustentável. Campo Grande. Embrapa Gado de Corte, 2011b. p. 13-24.

BARRETO, M.; SAHR, C. L. L. Os faxinais e ervamate: a incorporação da produção camponesa ao movimento da indústria capitalista. Terr@ Plural, v.1, n.2, p. 73-83, 2007.
BATISH, D. R.; KOHLI, R. K.; JOSE, S.; SINGH, H. $P$. Ecological basis of agroforestry. Boca Raton: CRC Press, 2008. 382 p.

BRASIL. Lei n.12651 (Novo Código Florestal), de 25 de maio de 2012. Disponível em: <http://www.planalto.gov.br/ccivil_03/_Ato20 11-2014/2012/Lei/L12651.htm> Acesso em: jun. 2017.

BRASIL. Ministério da Agricultura, Pecuária e Abastecimento. Plano Setorial de Mitigação e de Adaptação às Mudanças Climáticas para a Consolidação de uma Economia de Baixa Emissão de Carbono na Agricultura. Brasília, 2012. 173 p.

BRASIL. Ministério do Meio Ambiente. Monitoramento do desmatamento dos biomas brasileiros por satélite: acordo de Cooperação Técnica MMA/IBAMA. Monitoramento do Bioma Caatinga 2002 a 2008. Brasília, 2011. 46 p.

BRASIL. Resolução n. 458, de 16 de julho de 2013. Brasília: Diário Oficial da União de 18 de julho de 2013. Disponível em: http://www.mma.gov.br/port/conama/legiabr e.cfm?codlegi=696. Acesso em: jun. 2017.

CARVALHO, R.; GOEDERT, W. J.; ARMANDO, M. S. Atributos físicos da qualidade de um solo sob sistema agroflorestal. Pesq. Agropecuária Brasileira, v.39, n.11, p.1153-1155, 2004. https://doi.org/10.1590/S0100204X2004001100015

COSTA, R. B; ARRUDA, E. J; OLIVEIRA. L. C. S. Sistemas agrossilvipastoris como alternativa sustentável para a agricultura familiar. Interações: Revista Internacional de Desenvolvimento Local, v.3, n.5, p. 25-32, 2002.

http://dx.doi.org/10.20435/interacoes.v3i5.56 7.

COSTA, T. C. C.; OLIVEIRA, M. A. J.; ACCIOLY, L. J. O.; SILVA, F. H. B. B. Análise da degradação da caatinga no núcleo de desertificação do Seridó (RN/PB). Revista Brasileira de Engenharia Agrícola \& Ambiental, v.13, (supl.), p.961-974, 2009. https://doi.org/10.1590/S1415$\underline{43662009000700020}$ 
COUTO, W. R; ANJOS, L. H. C; WADT, P. G. S; PEREIRA, M.G. Atributos Edáficos e Resistência a Penetração em Áreas de Sistemas Agroflorestais no Sudoeste Amazônico. Ciência Florestal, v.26, n.3, p. 811-823, 2016. http://dx.doi.org/10.5902/1980509824210.

DIÓGENES, F. E. P; OLIVEIRA, A. K.; TORRES, S. B.; MAIA, S. S. S.; COELHO, M. F. B. Atividade alelopática do extrato de folhas Ziziphus joazeiro Mart. - Rhamnaceae. Revista Verde de Agroecologia e Desenvolvimento Sustentável, v.9, n.4, p. 01-04, 2014.

DUBOIS, J. C. L. Sistemas agroflorestais na Amazônia: avaliação dos principais avanços e dificuldades em uma trajetória de duas décadas. In: PORRO, R. (Ed.). Alternativa agroflorestal na Amazônia em transformação. Brasília: Embrapa Informação Tecnológica, 2009, p. 171-218.

DUQUE, J. G. O. Solo e água no polígono das secas. Fortaleza: Banco do Nordeste do Brasil, 2004. 334p.

ENGEL, V. L. Sistemas agroflorestais: conceitos e aplicações. In: SEMINÁRIO SOBRE SISTEMAS AGROFLORESTAIS E DESENVOLVIMENTO SUSTENTÁVEL, 2003, Campo Grande. Anais... Campo Grande, MS: Embrapra Gado de Corte, 2003. - vols. 1 CD-ROM.

FERREIRA, T. M.C.; VASCONCELOS, M.; CANTÃO, B. P.; SILVA, J. L.; KELWIN, A. W. Uso da terra com base no sistema agroflorestal: um estudo no município São Domingos do Capim, Pará. Rev. Ciências Agroambientais, v.14, n.2, p. 92-99, 2016.

GALZERANO, L.; MORGADO, E. Eucalipto em sistemas agrossilvipastoris. REDVET, Revista Electrónica de Veterinária, v.9, n.3, p. 1-6, 2008.

GAMA-RODRIGUES, E. F.; BARROS, N. F.; VIANA, A. P.; SANTOS, G. A. Alterações na biomassa e na atividade microbiana da serapilheira e do solo, em decorrência da substituição de cobertura florestal nativa por plantações de eucalipto, em diferentes sítios da região sudeste do Brasil. Revista Brasileira de Ciência do Solo, v.32, p. 1489-1499, 2008.
http://dx.doi.org/10.1590/S0100-

06832008000400013.

LEÃO, F. M.; DIONISIO, L. F. S.; SILVA, N. G. E.; BARBOSA, L. M.; OLIVEIRA, M. H. S.; NEVES, R. L. P. Fitossociologia em sistemas agroflorestais com diferentes idades de implantação no município de Medicilândia, PA. Revista Agro@mbiente On-line, v.11, n.1, p. 71-81, 2017.

MAIA, S. M. F. R. Frações de nitrogênio em Luvissolo sob sistemas agroflorestais e convencional no semi-árido cearense. Revista Brasileira de Ciência do Solo, v.32, p. 381-392, $2008 . \quad$ http://dx.doi.org/10.1590/S010006832008000100036.

MARTINS, J. C. R.; MENEZES, R. S. C.; SAMPAIO, E. V. S. B.; SANTOS, A. F.; NAGAI, M. A. Produtividade de biomassa em sistemas agroflorestais e tradicionais no Cariri Paraibano. Revista Brasileira de Engenharia Agrícola \& Ambiental, v.17, n.6, p.581-587, $2013 . \quad \quad h t t p: / / d x . d o i . o r g / 10.1590 /$ S141543662013000600002.

MARTINS, J.C.R.; FREITAS, A.D.S.; MENEZES, R.S.C.; SAMPAIO, E.V.S.B. Nitrogen symbiotically fixed by gliricidia and cowpea in an agroforestry system in semiarid Northeast Brazil. Pesquisa Agropecuária Brasileira, v.50, n.2, p. 178-184, 2015. http://dx.doi.org/10.1590/S0100204X2015000200010.

MARTINS, P. S. Dinâmica evolutiva em roças de caboclos amazônicos. Estudos avançados, v.19, n.53, p. 209-220, 2005. http://dx.doi.org/10.1590/S010340142005000100013.

MENDONÇA, E. S.; LEITE, L. F. C.; FERREIRA NETO, P. S. Cultivo de café em sistema agroflorestal: uma opção para recuperação de solos degradados. Revista Árvore, v.25, n.3, p. 375-383, 2001.

MOÇO, M. K. S.; GAMA-RODRIGUES, E. F.; GAMA-RODRIGUES, A. C.; MACHADO, R. C. R.; BALIGAR, V. C. Soil and litter fauna of cacao agroforestry systems in Bahia, Brazil. Agroforest Syst., v.76, n.1, p.127-138, 2008. http://dx.doi.org/10.1007/s10457-008-9178-6. 
MOONEM, A. C.; BARBIERI, P. Functional biodiversity: an agroecosystem approach. Agriculture, Ecosystems and Environment, n.127, n.1-2, p. 08-20, 2008. https://doi.org/10.1016/i.agee.2008.02.013.

MONTOYA, L. J.; MAZUCHOWSKI, J. Z. Estado da arte dos sistemas agroflorestais na região sul do Brasil. In: CONGRESSO BRASILEIRO SOBRE ECOSSISTEMAS AGROFLORESTAIS, 1., 1994, Porto Velho. Anais... Colombo: EmbrapaCNPF, 1994. p.77-96. (Documentos, 27).

OLIVEIRA, V. R.; SILVA, P. S. L.; PAIVA, H. N.; PONTES, F. S.T.; ANTONIO, R. P. Growth of Arboreal Leguminous Plants and Maize Yield in Agroforestry Systems. Revista Árvore, v.40, n.4, p.679-688, 2016. https://doi.org/10.1590/0100$\underline{67622016000400011}$

PALUDO, R.; COSTABEBER, J. A. Sistemas agroflorestais como estratégia de desenvolvimento rural em diferentes biomas brasileiros. Revista Brasileira de Agroecologia, v.7, n.2, p. 63-76, 2012.

PEREZ-MARIN, A. M.; MENEZES, R. S. C. Ciclagem de nutrientes via precipitação pluvial total, interna e escoamento pelo tronco em sistema agroflorestal com Gliricidia sepium. Revista Brasileira de Ciência do Solo, v.32, p. 2573-2579, 2008.

http://dx.doi.org/10.1590/S0100-

06832008000600034.

REZENDE, J. L. P.; OLIVEIRA, J. L. P. Análise econômica e social de projetos florestais. 3. ed. Viçosa, MG: Ed. da UFV, 2013. 385 p.

RIEGELHAUPT, E. M.; PAREYN, F. G. C.; GARIGLIO, M. A. O manejo florestal como ferramenta para o uso sustentável e conservação da caatinga. In: GARIGLIO, M. A.; SAMPAIO, E. V. S.; CESTARO, L. A.; KAGEYAMA, P. Y. (Org.). Uso Sustentável e Conservação dos Recursos Florestais da Caatinga. Brasília: Serviço Florestal Brasileiro, 2010.

SANTANA, J. A. S.; SOUTO, J. S. Diversidade e Estrutura Fitossociológica da Caatinga na Estação Ecológica do Seridó - RN. Revista de Biologia e Ciências da Terra, v.6, n.2, p. 232242, 2006.
SANTOS, M. J. C. Avaliação econômica de quatro modelos agroflorestais em áreas degradadas por pastagens na Amazônia Ocidental. 75 f. Dissertação (Mestrado), Universidade de São Paulo, Piracicaba. 2000.

SANTOS, M.J.C.; PAIVA, S.N. Os Sistemas Agroflorestais como Alternativa Econômica em Pequenas Propriedades Rurais: Estudo de Caso. Ciência Florestal, v.12, n.1, p. 135-141, 2002. http://dx.doi.org/10.5902/198050981707.

SILVA, D. C.; SILVA, M. L. N.; CURI, N.; OLIVEIRA, A. H.; SOUZA, F. S.; MARTINS, S. G.; MACEDO, R. L. G. Atributos do solo em sistemas agroflorestais, cultivo convencional e floresta nativa. Revista de Estudos Ambientais, v.13, n.1, p.77-86, 2011. http://dx.doi.org/10.7867/1983-

1501.2011v13n1p77-86.

SILVA, G.J. F.; ALMEIDA, N. V. Degradação Ambiental no Município de Parari PB: Uma Análise por Meio de Sensoriamento Remoto. Revista Geografar, v.10, n.2, p.140-164, 2015. http://dx.doi.org/10.5380/geografar.v10i2.372 $\underline{85}$.

SILVA, P. C. G.; GUIMARÃES FILHO, C. Eixo Tecnológico da Ecorregião Nordeste. In: SOUSA, I.S.F.de. (Ed.) Agricultura familiar na dinâmica da pesquisa agropecuária. Brasília, DF: Embrapa Informação Tecnológica, 2006. p.109-123.

SILVA, R. A.; CRESTE, J. E.; MEDRADO, M. J. S.; RIGOLIN, I. M. Sistemas integrados de produção - o novo desafio para a agropecuária brasileira. Colloquium Agrariae, v.10, n.1, p. 55-68, 2014. http://dx.doi.org/10.5747/ca.2014.v10.n1.a10 $\underline{0}$.

SOUZA, A. N.; OLIVEIRA, A. D.; SCOLFORO, J. R. S.; REZENDE, J. L. P.; MELLO, J. M. Viabilidade econômica de um sistema agroflorestal. Revista Cerne, v.13, n.1, p. 96-106. 2007.

TORRES, C. M. M. E.; JACOVINE, L. A. G.; OLIVEIRA NETO, S. N.; BRIANEZI, D.; ALVES, E. B. B. M. Sistemas agroflorestais no Brasil: uma abordagem sobre a estocagem de carbono. Pesq. Florestal Brasileira, v.34, n.79, p. 235- 
244, 2014.

https://doi.org/10.4336/2014.pfb.34.79.633.

UMRANI, R.; JAIN, C. K. Agroforestry Systems and Practices. Jaipur: Oxford Book Company, 2010, 298 p.

Recebido para publicação em 10/04/2018

Revisado em 03/07/2018

Aceito em 04/07/2018 